\title{
Effect of Dissolved Oxygen Concentrations on Specific Microbial Activities and Their Metabolic Products in Simultaneous Sulfur and Nitrogen Removal
}

\author{
W. Thongnueakhaeng and P. Chaiprasert
}

\begin{abstract}
This work investigated simultaneous removal of sulfur and nitrogen compounds under micro oxygen. Different ranges of dissolved oxygen (DO) concentration were used, from 0.05-0.10, 0.10-0.15, 0.15-0.20, 0.20-0.25 and $0.25-0.30 \mathrm{mg} / \mathrm{L}$, to study the effect of DO on specific microbial activities and their metabolic products. The results indicated that the optimal DO concentration was $0.10-0.15 \mathrm{mg} / \mathrm{L}$. This condition provided removal efficiency of $\mathrm{SO}_{4}{ }^{2-}-\mathrm{S}$ and $\mathrm{NH}_{4}{ }^{+} \mathrm{N}$ at $71.2 \%$ and $62.8 \%$, respectively. In addition, $\mathrm{S}^{0}$ and $\mathrm{N}_{2}$ gas were the required end products for this study. The yield of $S^{0}$ and $N_{2}$ was 0.63

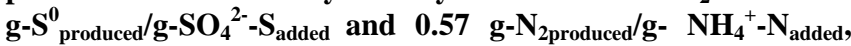
respectively. Activities of sulfate reducing bacteria (SRB), sulfide oxidizing bacteria (SOB), nitrifier and denitrifier were $0.098,0.361, \quad 0.080$ and 0.169 g-substrate consumed $_{\text {d }} / \mathrm{g}-\mathrm{VSS} / \mathrm{d}$, respectively. At the lowest $\mathrm{DO}$ of $0.05-0.10 \mathrm{mg} / \mathrm{L}$, nitrifier was inhibited, leading to decreasing $\mathrm{NH}_{4}{ }^{+}-\mathrm{N}$ removal efficiency and $\mathrm{N}_{2}$ yield. However, sulfate removal and $\mathrm{S}^{\mathbf{0}}$ yield slightly increased. When DO concentrations reached $0.15-0.30 \mathrm{mg} / \mathrm{L}$, sulfate removal efficiency and $\mathrm{S}^{\mathbf{0}}$ yields decreased significantly. In addition, SRB activity was inhibited significantly while activity of SOB was not significantly different. In contrast, the activity of nitrifier was enhanced by increasing oxygen to peak removal of ammonium. However, $\mathrm{N}_{2}$ gas production was increased slightly because nitrate reduction to $\mathrm{N}_{2}$ was inhibited at high DO concentrations.
\end{abstract}

Index Terms-Simultaneous removal, sulfate, ammonium nitrogen, specific microbial activity, metabolic product.

\section{INTRODUCTION}

Contamination of ground and surface water with sulfur and nitrogen compounds is a major environmental concern [1], [2]. The discharge of sulfate rich wastewater into surface water contributes to the increasing of the corrosion potential of receiving water due to the biological reduction of sulfate to sulfide under anaerobic conditions [2]. In addition, nitrogen compounds afford risks associated with toxicity and bad odor in water, leading to eutrophication and serious ecological damage to the receiving water bodies [1], [3].

Manuscript received May 15, 2014; revised July 17, 2014. This work was supported in part by the Joint Graduated School of Energy and Environment, and Excellent Center of Waste Utilization and Management, King Mongkut's University of Technology Thonburi, by Office of the Higher Education Commission (OHEC), by Agricultural research Development Agency (ARDA) and by Thaksin University, Thailand.

W. Thongnueakhaeng is with The Joint Graduate School of Energy and Environment (JGSEE), King Mongkut's University of Technology Thonburi, Thailand, 10140 (e-mail: vikandat@hotmail.com).

P. Chaiprasert is with the Division of Biotechnology, School of Bioresources and Technology, King Mongkut's University of Technology Thonburi, Thailand, 10140 (e-mail: pawinee.cha@kmutt.ac.th).
In order to remove sulfate and nitrogen contaminants, biological treatments are preferred technologies rather than physical-chemical methods, which are expensive and may generate toxic residuals [4]. The conventional biological process to treat sulfate rich wastewater consists of two processes, sulfate reducing to sulfide by sulfate reducing bacteria (SRB) under anaerobic condition, and sulfide oxidizing to elemental sulfur $\left(\mathrm{S}^{0}\right)$ by sulfide oxidation bacteria (SOB) under micro-aeration conditions or by autotrophic denitrifier under anaerobic conditions in presence of nitrate. Additionally, conventional biological nitrogen removal processes consist of the nitrification process under aerobic conditions and the denitrification process under anaerobic conditions. A common drawback of these processes is the need of separated units for anaerobic and aerobic conditions, which increases capital and operation costs. However, previous literatures have reported that anaerobic and aerobic microorganisms can work together in a single reactor under micro aeration conditions. Reference [5] studied nitrogen removal by simultaneous nitrification and denitrification in a single reactor. They found that a DO concentration around $0.5 \mathrm{mg} / \mathrm{L}$ was suitable for achieving a nitrification rate equal to the denitrification rate; the average nitrogen removal efficiency was 85\% [5]. Additionally, reference [6] revealed that DO levels can be used to manipulate SRB and SOB reactions in a single reactor. This work demonstrated that at DO $0.10-0.12 \mathrm{mg} / \mathrm{L}$, the removal efficiency for sulfate reached $81.5 \%$ and the recovery of $\mathrm{S}^{0}$ peaked at $71.8 \%$. Furthermore, combined sulfur and nitrogen compounds in wastewater can stimulate sulfide and nitrate removal efficiency though the sulfide oxidation denitrification process [7]. In addition, reference [8] reported that in systems that contain sulfide and nitrate, adding micro oxygen at $0.8 \mathrm{mg} / \mathrm{L}$ can stimulated the activities of sulfide oxidation and denitrfication, and can reduced the inhibition of sulfide on denitrifier.

The literature reviews demonstrate that both anaerobic and aerobic microorganisms for sulfur and nitrogen compound removal can work under micro oxygen conditions. Additionally, the level of dissolved oxygen (DO) is an effective process parameter to regulate the activities of microorganisms and metabolic products. Moreover, simultaneous sulfate and nitrogen compound removal under micro oxygen has been study of interest. Therefore, a batch experiment was conducted in this research to study the effect of DO concentrations on specific microbial activities and their metabolic products in simultaneous sulfate and nitrogen compound removal systems. 


\section{MATERIALS AND METHODS}

\section{A. Seeding Sludge and Synthetic Wastewater}

Seeding sludge for this study was collected from an anaerobic open pond of a swine farm. The concentration of the microbial sludge was $20 \mathrm{~g}$-VSS/L. Synthetic wastewater was prepared to simulate concentrated latex wastewater by using lactic acid, anhydrous sodium sulfate $\left(\mathrm{Na}_{2} \mathrm{SO}_{4}\right)$ and ammonium chloride $\left(\mathrm{NH}_{4} \mathrm{Cl}\right)$ as sources of carbon, sulfate and ammonium nitrogen, respectively [6], [9]. In the reactor, $\mathrm{SO}_{4}{ }^{2-}, \quad \mathrm{NH}_{4}{ }^{+} \mathrm{N}$ and $\mathrm{COD}$ was added to an initial concentration of 1,000, 222.2 and 4,000 mg/L respectively as shown in Table I. The influent $\mathrm{pH}$ value was maintained at 7.0 by dosing $\mathrm{NaOH}$ [9]. $1 \mathrm{~mL}$ of trace element solution was added to $1 \mathrm{~L}$ of feed with compositions shown in Table II [10].

TABLE I: CHARACTERISTICS OF SYNTHETIC WASTEWATER FOR OPTIMAL DO EXPERIMENT

\begin{tabular}{|c|c|}
\hline Parameters & Values \\
\hline $\mathrm{SO}_{4}^{2-} \quad(\mathrm{mg} / \mathrm{L})$ & 1,000 \\
\hline $\mathrm{SO}_{4}{ }^{2-}-\mathrm{S}(\mathrm{mg} / \mathrm{L})$ & 333 \\
\hline COD (mg/L) & 4,000 \\
\hline $\mathrm{NH}_{4}{ }^{+}-\mathrm{N}(\mathrm{mg} / \mathrm{L})$ & 222 \\
\hline $\mathrm{COD} / \mathrm{SO}_{4}{ }^{2-}$ & 4.0 \\
\hline $\mathrm{S} / \mathrm{N}$ & 1.5 \\
\hline $\mathrm{COD} / \mathrm{N}$ & 18 \\
\hline $\mathrm{pH}$ & 7.0 \\
\hline
\end{tabular}

TABLE II: CHEMICAL COMPOSITION OF BASAL MEDIUM FOR OPTIMAL DO CONCENTRATION EXPERIMENT

\begin{tabular}{llll}
\hline \hline \multicolumn{1}{c}{ Mineral medium } & \multicolumn{3}{l}{ Trace element solution } \\
\hline $\mathrm{KH}_{2} \mathrm{PO}_{4}$ & $4.50 \mathrm{~g} / \mathrm{L}$ & EDTA & $5.00 \mathrm{~g} / \mathrm{L}$ \\
$\mathrm{K}_{2} \mathrm{HPO}_{4}$ & $3.00 \mathrm{~g} / \mathrm{L}$ & $\mathrm{CuSO}_{4} \cdot 5 \mathrm{H}_{2} \mathrm{O}$ & $1.57 \mathrm{~g} / \mathrm{L}$ \\
$\mathrm{NaCl}$ & $0.20 \mathrm{~g} / \mathrm{L}$ & $\mathrm{CaCl}_{2} \cdot 2 \mathrm{H}_{2} \mathrm{O}$ & $5.54 \mathrm{~g} / \mathrm{L}$ \\
$\mathrm{NaHCO}_{3}$ & $3.50 \mathrm{~g} / \mathrm{L}$ & $\mathrm{MnCl}_{2} \cdot 4 \mathrm{H}_{2} \mathrm{O}$ & $5.00 \mathrm{~g} / \mathrm{L}$ \\
$\mathrm{Trace}$ element solution & $1.3 \mathrm{~mL} / \mathrm{L}$ & $\left(\mathrm{NH}_{4}\right)_{6} \mathrm{Mo}_{7} \mathrm{O}_{24} \cdot 4 \mathrm{H}_{2} \mathrm{O}$ & $1.10 \mathrm{~g} / \mathrm{L}$ \\
& & $\mathrm{FeSO}_{4} \cdot 7 \mathrm{H}_{2} \mathrm{O}$ & $5.00 \mathrm{~g} / \mathrm{L}$ \\
& & $\mathrm{CoCl}_{2} \cdot 6 \mathrm{H}_{2} \mathrm{O}$ & $1.60 \mathrm{~g} / \mathrm{L}$ \\
& & $\mathrm{MgCl}_{2} \cdot 5 \mathrm{H}_{2} \mathrm{O}$ & $5.00 \mathrm{~g} / \mathrm{L}$ \\
\hline \hline
\end{tabular}

Note: Modified from Beristain-Cardoso, et al., 2010

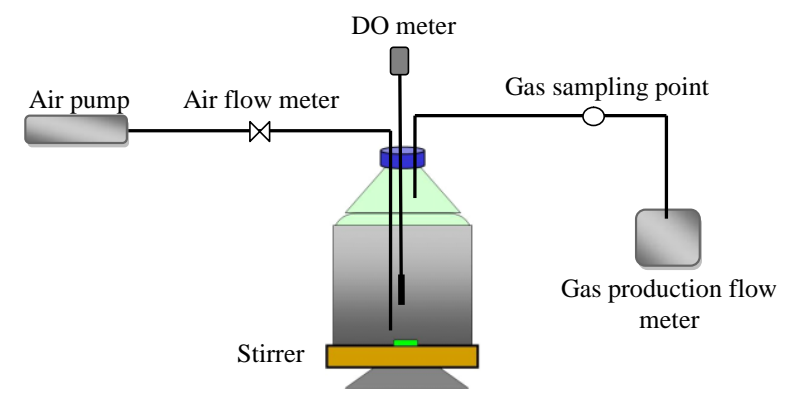

Fig. 1. Schematic diagram of optimized condition experiment for sulfate and nitrogen compound removal.

\section{B. Experimental Set up}

Experiments were conducted in a batch system for simultaneous sulfur and nitrogen compound removal. The experiments were carried out in a 1,200 mL closed reactor as shown in Fig. 1. Synthetic wastewater and biomass were added in the reactor with a working volume of 1,000 mL. Air was supplied by air pump to control the oxygen concentration in ranges of $0.05-0.10,0.10-0.15,0.15-0.20,0.20-0.25$ and $0.25-0.30 \mathrm{mg} / \mathrm{L}$. The batch tests were incubated at ambient temperature $\left(31.4 \pm 2.8^{\circ} \mathrm{C}\right)$ for 12 hours. The DO concentration in the reactor was measured every 10 seconds by a Luminescent Dissolved Oxygen (LDO) meter.

At the end of the experiment, microbial sludge samples were obtained to study activities of SRB, SOB, nitrifier and denitrifier. Mixed liquor samples were collected to determine metabolic products. Furthermore, COD and $\mathrm{pH}$ were measured by Close reflux, calorimetric method [11] and $\mathrm{pH}$ meter, respectively.

\section{Microbial Activity Test}

Activities of SRB, SOB, nitrifier and denitrifier were studied in this work. Microbial activity experiments were conducted triplicate in batch system. The controls were performed by supplement medium without seed sludge.

\section{1) Sulfate reducing bacteria (SRB) activity test}

Measurement of the sulfate reduction rate was performed at $30 \pm 2{ }^{\circ} \mathrm{C}$ in a $120 \mathrm{~mL}$ vial with a final biomass concentration of $2 \mathrm{~g}$-VSS/L. The mineral medium contained, in $\mathrm{mg} / \mathrm{L}, 270 \quad \mathrm{KH}_{2} \mathrm{PO}_{4} ; 350 \quad \mathrm{~K}_{2} \mathrm{HPO}_{4} ; 530 \mathrm{NH}_{4} \mathrm{Cl} ; 100$ $\mathrm{MgCl}_{2} \cdot 6 \mathrm{H}_{2} \mathrm{O} ; 75 \mathrm{CaCl}_{2} \cdot 2 \mathrm{H}_{2} \mathrm{O} ; 1,200 \mathrm{NaHCO}_{3}$ [12]. Vials were flushed with helium gas for 5 minutes to expel oxygen gas and subsequently sealed with butyl rubber stoppers and aluminum seals [3], [12]. Lactic acid and $\mathrm{Na}_{2} \mathrm{SO}_{4}$ were added to the medium to give final concentrations of $6.0 \mathrm{~g}-\mathrm{COD} / \mathrm{L}$

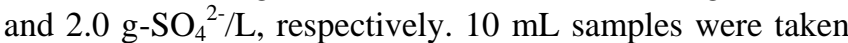
and centrifuged, $5 \mathrm{~mL}$ of supernatant was then analyzed for sulfate reduction.

\section{2) Sulfide oxidizing bacteria (SOB) activity test}

The SOB activities were tested in a $120 \mathrm{~mL}$ Erlenmeyer flask. The temperature and $\mathrm{pH}$ of all tests were maintained at $30 \pm 2{ }^{\circ} \mathrm{C}$ and 7.0, respectively. Medium and a known amount of sludge were added in flask with a total volume of $100 \mathrm{~mL}$ and total biomass concentration was $2 \mathrm{~g}$-VSS/L. The medium contained $4.13 \pm 0.01 \mathrm{~g} / \mathrm{L}$ of thiosulfate and basal medium consisted of nutrient solution as shown in Table III. The liquor samples were collected to determine thiosulfate consumption every day in the time of the activity test.

\section{3) Nitrifier activity test}

TABLE III: CHEMICAL COMPOSITION OF NUTRIENT SOLUTION FOR SOB, NITRIFIER AND DENITRIFIER ACTIVITY TEST [13]

\begin{tabular}{lllc}
\hline \hline Mineral medium & \multicolumn{3}{c}{$\begin{array}{l}\text { Trace element } \\
\text { solution }\end{array}$} \\
\hline $\mathrm{KNO}_{3}$ & $2.0 \mathrm{~g} / \mathrm{L}$ & EDTA & $50.0 \mathrm{~g} / \mathrm{L}$ \\
$\mathrm{KH}_{2} \mathrm{PO}_{4}$ & $2.0 \mathrm{~g} / \mathrm{L}$ & $\mathrm{CaCl}_{2} \cdot 2 \mathrm{H}_{2} \mathrm{O}$ & $7.3 \mathrm{~g} / \mathrm{L}$ \\
$\mathrm{NH}_{4} \mathrm{Cl}$ & $1.0 \mathrm{~g} / \mathrm{L}$ & $\mathrm{FeSO}_{4} \cdot 7 \mathrm{H}_{2} \mathrm{O}$ & $5.0 \mathrm{~g} / \mathrm{L}$ \\
$\mathrm{NaHCO}_{3}$ & $2.0 \mathrm{~g} / \mathrm{L}$ & $\mathrm{MnCl}_{2} \cdot 4 \mathrm{H}_{2} \mathrm{O}$ & $2.5 \mathrm{~g} / \mathrm{L}$ \\
$\mathrm{MgSO}_{4} \cdot 7 \mathrm{H}_{2} \mathrm{O}$ & $0.8 \mathrm{~g} / \mathrm{L}$ & $\mathrm{ZnSO}_{4} \cdot 7 \mathrm{H}_{2} \mathrm{O}$ & $2.2 \mathrm{~g} / \mathrm{L}$ \\
$\mathrm{Trace}$ element solution & $1.0 \mathrm{~mL} / \mathrm{L}$ & $\left(\mathrm{NH}_{4}\right)_{6} \mathrm{Mo}_{7} \mathrm{O}_{24} \cdot 4 \mathrm{H}_{2} \mathrm{O}$ & $0.5 \mathrm{~g} / \mathrm{L}$ \\
& & $\mathrm{CaSO}_{4} \cdot 5 \mathrm{H}_{2} \mathrm{O}$ & $0.2 \mathrm{~g} / \mathrm{L}$ \\
& & $\mathrm{NaOH}$ & $11.0 \mathrm{~g} / \mathrm{L}$ \\
\hline \hline
\end{tabular}

The ammonium oxidation rate measurement was 
performed at ambient temperature $\left(31 \pm 2{ }^{\circ} \mathrm{C}\right)$ in a $120 \mathrm{~mL}$ Erlenmeyer flask. Medium (pH 7.0) and biomass were added in flask with a total volume of $100 \mathrm{~mL}$ and total biomass concentration was $2 \mathrm{~g}$-VSS/L. The medium contained $1.00 \pm 0.01 \mathrm{~g} / \mathrm{L}$ of $\mathrm{NH}_{4}{ }^{+}-\mathrm{N}$ and basal medium consisted of nutrient solution as shown in Table III. The liquor samples were collected to determine consumed ammonium nitrogen and produced nitrate-nitrite every day in the time of the activity test.

\section{4) Denitrifier activity test}

Measurement of the nitrate reduction rate was performed in a $120 \mathrm{~mL}$ vial at $30 \pm 2{ }^{\circ} \mathrm{C}$ with final biomass concentration of $2 \mathrm{~g}-\mathrm{VSS} / \mathrm{L}$. Medium and biomass were added in a vial with a total volume of $100 \mathrm{~mL}(\mathrm{pH} 7.0)$. The medium contained $1.00 \mathrm{~g}-\mathrm{NO}_{3}{ }^{-} \mathrm{-N} / \mathrm{L}$. Lactic acid was added to give final concentrations of $3.5 \mathrm{~g} \mathrm{COD} / \mathrm{L}$. The basal medium consisted of nutrient solution as shown in Table III. Vials were flushed with helium gas for $5 \mathrm{~min}$ to remove oxygen from both the aqueous phase and headspace and sealed with butyl rubber stoppers and aluminum crimps [3]. Gas samples were collected and analyzed for $\mathrm{N}_{2}$ gas production. $10 \mathrm{~mL}$ of samples were taken and centrifuged, and supernatant was then analyzed for consumed $\mathrm{NO}_{3}{ }^{-} \mathrm{N}$ every day in the time of the activity test.

\section{Analytical Procedures}

To determine the metabolic products from simultaneous sulfate and nitrogen compound removal, gas samples were collected and analyzed for $\mathrm{H}_{2} \mathrm{~S}$ and $\mathrm{N}_{2}$ every hour. At the end of the experiment, concentrations of $\mathrm{SO}_{4}{ }^{2-}, \mathrm{S}^{2-}, \mathrm{S}_{2} \mathrm{O}_{3}{ }^{2-}, \mathrm{NH}_{4}{ }^{+}$, $\mathrm{NO}_{3}{ }^{-}$and $\mathrm{NO}_{2}^{-}$in liquor samples were measured after centrifugation at $4500 \mathrm{rpm}$ for 10 minutes. Sulfate was analyzed according to Turbidimetric method [11]. Aqueous sulfide $\left(\mathrm{H}_{2} \mathrm{~S}_{(\mathrm{aq})}+\mathrm{HS}^{-}+\mathrm{S}^{2-}\right)$ and thiosulfate were determined by Iodometric method [11]. Macro-Kjeldahl method [11] was used to measure ammonium nitrogen. Nitrate and nitrite were determined by spectrophotometric method. $\mathrm{S}^{0}$ in mixed liquor was determined by technical development based on the sulfite method [14]. Gas samples were collected and analyzed for $\mathrm{H}_{2} \mathrm{~S}$ and $\mathrm{N}_{2}$. Concentrations of $\mathrm{N}_{2}$ gas was determined by gas chromatography (GC-2010, Molecular sieve, $50{ }^{\circ} \mathrm{C}, \mathrm{He}$ $25 \mathrm{~mL} / \mathrm{min}$ ).

\section{RESUlTS AND DISCUSSION}

\section{A. Dissolved Oxygen (DO) Concentration Control}

To study the effect of DO concentrations on specific microbial activities and their metabolic products for simultaneous sulfate and nitrogen compound removal, different ranges of dissolved oxygen (DO) concentrations were used. Fig. 2 shows that during 12 hours of inoculation, the DO concentrations in batch reactor were not stable. However, the DO concentrations were controlled in the ranges of $0.05-0.10,0.10-0.15,0.15-0.20,0.20-0.25$ and $0.25-0.30 \mathrm{mg} / \mathrm{L}$.

B. Effect of DO on Specific Microbial Activities and Metabolic Products in Sulfur Compound Removal

Table IV shows that the highest $\mathrm{SO}_{4}{ }^{2-}-\mathrm{S}$ removal efficiency of $78.0 \%$ was found at the lowest DO concentrations of $0.05-0.10 \mathrm{mg} / \mathrm{L}$. In addition, $\mathrm{SO}_{4}{ }^{2-}-\mathrm{S}$ removal efficiency was decreased to $71.3,48.4,25.5$ and $5.6 \%$ at DO concentrations of $0.10-0.15,0.15-0.20$, $0.20-0.25$ and $0.25-0.30 \mathrm{mg} / \mathrm{L}$, respectively. The results demonstrated that the sulfate reducing rate by SRB was inhibited significantly when DO concentration increased to $0.15-0.30 \mathrm{mg} / \mathrm{L}$. Furthermore, sulfate reducing nearly failed at DO $0.25-0.30 \mathrm{mg} / \mathrm{L}$. These observations correspond to results of the SRB activity test, the highest SRB activity of $0.101{\mathrm{~g}-\mathrm{SO}_{4}}^{2-}-\mathrm{S} / \mathrm{g}-\mathrm{VSS} / \mathrm{d}$ was found at DO $0.05-0.10 \mathrm{mg} / \mathrm{L}$.
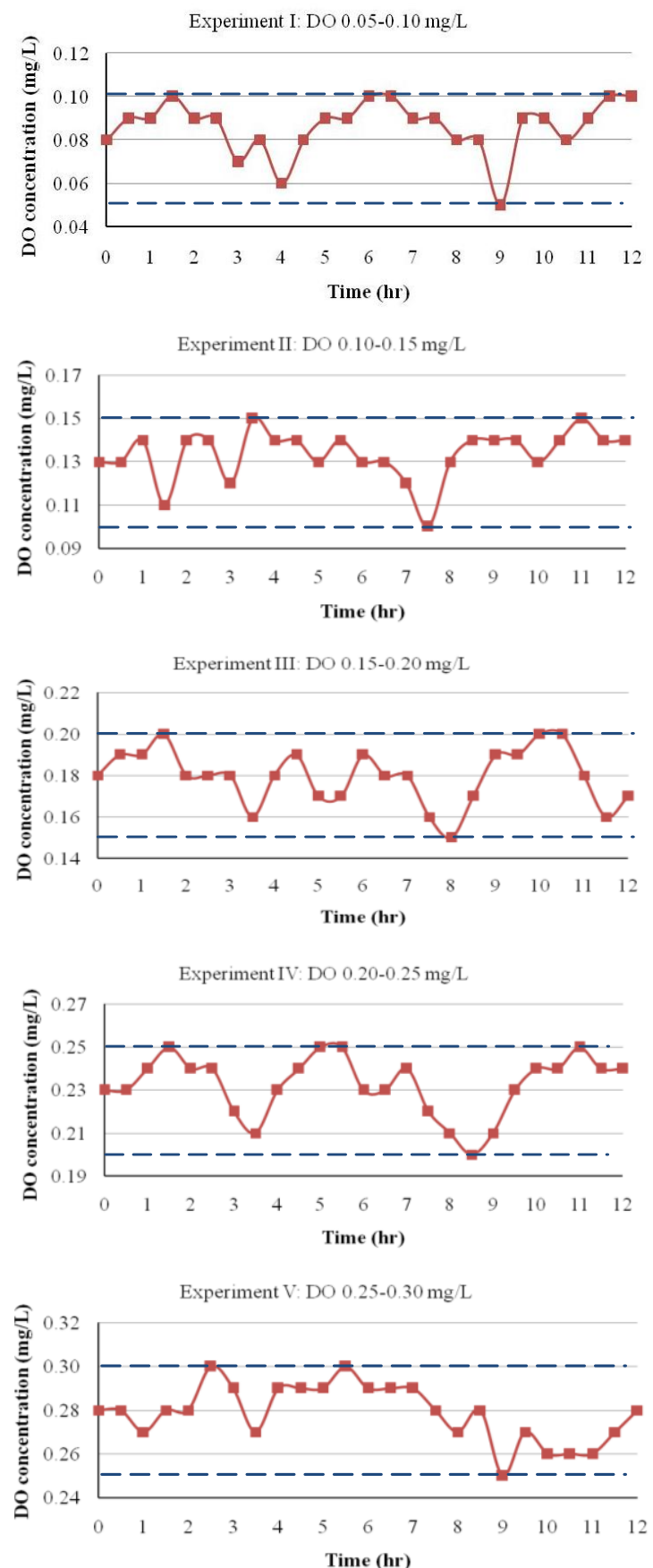

Fig. 2. DO concentration in batch reactor of each experiment.

In addition, the SRB activities were reduced to 0.098 ,

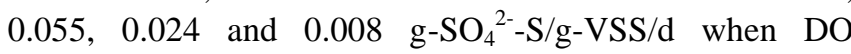
concentrations reached $0.10-0.15,0.15-0.20,0.20-0.25$ and 0.25-0.30 mg/L, respectively. 
TABLE IV: EFFECT OF DO CONCENTRATION ON SULFATE REMOVAL AND ACTIVITIES OF SRB AND SOB

\begin{tabular}{|c|c|c|c|c|}
\hline \multirow[b]{2}{*}{$\begin{array}{c}\mathrm{DO} \\
(\mathrm{mg} / \mathrm{L})\end{array}$} & \multirow[b]{2}{*}{$\mathrm{pH}$} & \multirow[b]{2}{*}{$\begin{array}{c}\mathrm{SO}_{4}{ }^{2-}-\mathrm{S}_{\text {removed }} \\
\mathrm{mg} / \mathrm{L}(\%)\end{array}$} & \multicolumn{2}{|c|}{ Specific microbial activity } \\
\hline & & & $\begin{array}{c}\mathrm{SRB} \\
\left(\mathrm{g} \mathrm{SO}_{4}{ }^{2-}-\mathrm{S} /\right. \\
\mathrm{g} \mathrm{VSS} / \mathrm{d})\end{array}$ & $\begin{array}{c}\mathrm{SOB} \\
\left(\mathrm{g} \mathrm{S}_{2} \mathrm{O}_{3}^{-}-\mathrm{S} /\right. \\
\mathrm{g} \mathrm{VSS} / \mathrm{d})\end{array}$ \\
\hline $0.05-0.10$ & 7.78 & $262.6(78.0)$ & $0.101 \pm 0.005$ & $0.353 \pm 0.008$ \\
\hline $0.10-0.15$ & 7.72 & $239.7(71.3)$ & $0.098 \pm 0.005$ & $0.361 \pm 0.007$ \\
\hline $0.15-0.20$ & 7.56 & $161.6(48.4)$ & $0.055 \pm 0.007$ & $0.350 \pm 0.006$ \\
\hline $0.20-0.25$ & 7.50 & $84.8(25.5)$ & $0.024 \pm 0.006$ & $0.341 \pm 0.007$ \\
\hline $0.25-0.30$ & 7.46 & $18.6(5.6)$ & $0.008 \pm 0.008$ & $0.335 \pm 0.005$ \\
\hline
\end{tabular}

The findings of some researchers identified that SRB was able to tolerate and even respire oxygen [15]-[17]. However, reference [6] described that SRB was inhibited at high DO concentration leading to a decreasing of sulfate removal efficiency. They also indicated that SRB was inhibited significantly at DO of $0.3 \mathrm{mg} / \mathrm{L} \mathrm{[6].}$

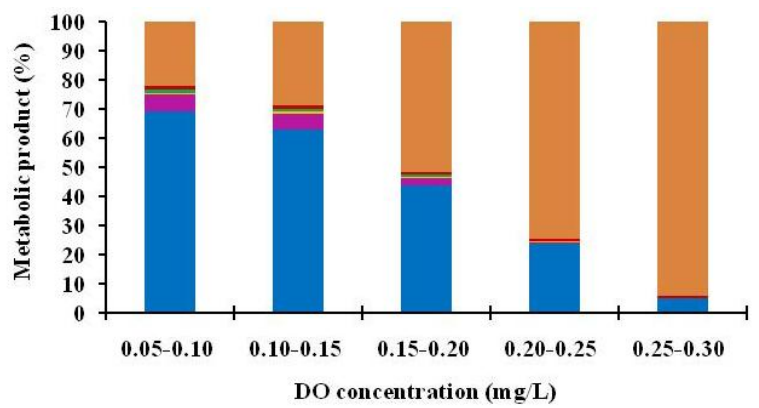

$\varpi \mathrm{S}^{0}$-S produced $\square \mathrm{S}^{2-}-\mathrm{S}$ produced $\square \mathrm{S}_{2} \mathrm{O}_{3}{ }^{2-}-\mathrm{S}$ produced $\varpi \mathrm{H}_{2} \mathrm{~S}$ (gas) produced $\square$ other form of $\mathrm{S} \backsim \mathrm{SO}_{4}{ }^{2-}-\mathrm{S}$ remaining

Fig. 3. Effect of DO on metabolic products of the sulfate removal process.

According to reference [18], metabolic products of sulfide reduction by SRB were sulfide and thiosulfate, despite both forms of sulfur were found in small amounts in this study as shown in Fig. 3. These observations show that sulfide oxidation by SOB was nearly complete at all DO concentrations. Additionally, the SOB activities were not significantly different at all DO concentrations. The results also supported that chemical sulfide oxidation could be ignored during the present work based on the fact that thiosulfate was the main product of chemical sulfide oxidation [19], [20].

This experiment also showed that the main metabolic product of sulfate removal was $S^{0}$. The produced $S^{0}$ can be separated from the liquid stream and recovered as fertilizer, raw material for sulfuric acid production and substrates for bioleaching processes [21]. Production of $S^{0}$ was reduced when DO concentration increased. With inoculation under DO concentration of $0.05-0.15 \mathrm{mg} / \mathrm{L}, \mathrm{S}^{0}$ production was higher than remaining $\mathrm{SO}_{4}{ }^{2-}-\mathrm{S}$. However, when $\mathrm{DO}$ concentration was up to $0.15-0.30 \mathrm{mg} / \mathrm{L}$, the main sulfur compound in batch experiment was $\mathrm{SO}_{4}{ }^{2-}-\mathrm{S}$. Reference [8] reported that at DO less than $0.1 \mathrm{mg} / \mathrm{L}, \mathrm{S}^{0}$ was the main product of the sulfide oxidation process. They also explained that production of $\mathrm{S}^{0}$ by $\mathrm{SOB}$ decreased at high DO concentration [8]. Reference [6] also indicated that DO concentrations for simultaneous sulfate reduction and sulfide oxidation were in the ranges of $0.08-0.26 \mathrm{mg} / \mathrm{L}$. The literature reviews corresponded to results of this experiment; sulfate removal efficiency and $\mathrm{S}^{0}$ production were decreased when DO concentrations were increased.

\section{Effect of DO on Specific Microbial Activities and Metabolic Products in Nitrogen Compound Removal}

With inoculation under the lowest DO concentration of 0.05-0.10 mg/L, the lowest $\mathrm{NH}_{4}{ }^{+}-\mathrm{N}$ removal efficiency of $48.5 \%$ was found as shown in Table V. In addition, removal efficiency of $\mathrm{NH}_{4}{ }^{+}-\mathrm{N}$ was increased to $62.8,69.1,72.9$ and $76.4 \%$ at DO concentrations of $0.10-0.15,0.15-0.20$, $0.20-0.25$ and $0.25-0.30 \mathrm{mg} / \mathrm{L}$, respectively.

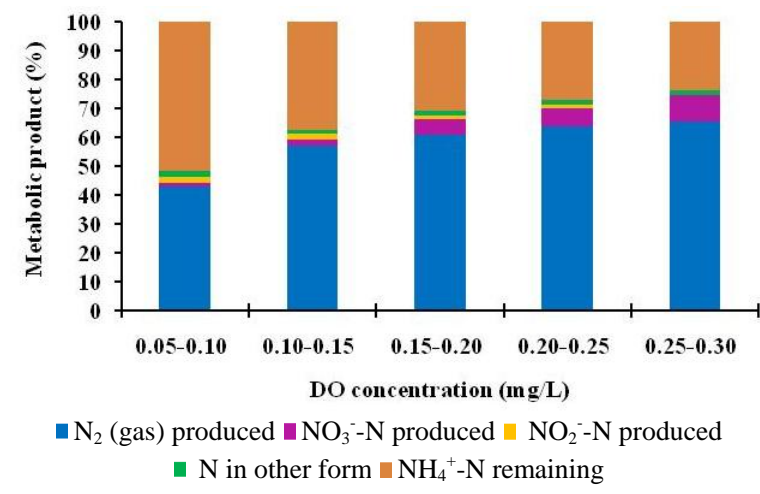

Fig. 4. Effect of DO on metabolic products of the nitrogen removal process.

TABLE V: EFFECT OF DO ON AMMONIUM NITROGEN REMOVAL AND ACTIVITY OF NITRIFIER AND DENITRIFIER

\begin{tabular}{ccccc}
\hline \hline & & $\mathrm{NH}_{4}{ }^{+}-\mathrm{N}_{\text {removed }}$ & \multicolumn{2}{c}{ Specific microbial activity } \\
\cline { 4 - 5 } $\mathrm{DO}(\mathrm{mg} / \mathrm{L})$ & $\mathrm{pH}$ & $\mathrm{mg} / \mathrm{L}(\%)$ & $\begin{array}{c}\text { Nitrifier } \\
\left(\mathrm{g} \mathrm{NH}_{4}{ }^{+} \mathrm{N} / \mathrm{g}\right. \\
\mathrm{VSS} / \mathrm{d})\end{array}$ & $\begin{array}{c}\text { Denitrifier } \\
\left(\mathrm{g} \mathrm{NO}_{3}-\mathrm{N} / \mathrm{g}\right. \\
\mathrm{VSS} / \mathrm{d})\end{array}$ \\
\hline $0.05-0.10$ & 7.78 & $107.0(48.5)$ & $0.065 \pm 0.005$ & $0.174 \pm 0.005$ \\
$0.10-0.15$ & 7.72 & $139.8(62.8)$ & $0.080 \pm 0.005$ & $0.169 \pm 0.004$ \\
$0.15-0.20$ & 7.56 & $153.6(69.1)$ & $0.087 \pm 0.004$ & $0.161 \pm 0.005$ \\
$0.20-0.25$ & 7.50 & $163.2(72.9)$ & $0.091 \pm 0.005$ & $0.157 \pm 0.005$ \\
$0.25-0.30$ & 7.46 & $173.0(76.4)$ & $0.098 \pm 0.004$ & $0.151 \pm 0.003$ \\
\hline \hline
\end{tabular}

Reference [22] described that nitrifying bacteria need $\mathrm{O}_{2}$ to oxidize $\mathrm{NH}_{4}{ }^{+}-\mathrm{N}$ to be nitrite and nitrate nitrogen. Therefore, operation under low DO concentration resulted in a decrease in $\mathrm{NH}_{4}{ }^{+}-\mathrm{N}$ removal efficiency [22].

Moreover, accumulation of sulfide was found in this experiment under inoculation at low DO concentration as shown in Fig. 3 Reference [10] explained that sulfide was toxic to nitrifying bacteria. Table $\mathrm{V}$ shows that nitrifier activities were reduced when DO concentration decreased. The activity of nitrifier from DO $0.25-0.30 \mathrm{mg} / \mathrm{L}$ inoculation was $0.098 \mathrm{~g}-\mathrm{NH}_{4}{ }^{+}-\mathrm{N} / \mathrm{g}-\mathrm{VSS} / \mathrm{d}$. Nitrifier activities were decreased to $0.091,0.087,0.080$ and 0.065 $\mathrm{g}-\mathrm{NH}_{4}{ }^{+}-\mathrm{N} / \mathrm{g}-\mathrm{VSS} / \mathrm{d}$ when DO dropped to $0.20-0.25$, $0.15-0.20,0.10-0.15$ and $0.05-0.10 \mathrm{mg} / \mathrm{L}$, respectively.

The main metabolic product of nitrogen compounds removal was $\mathrm{N}_{2}$ gas as shown in Fig. 4. Although, removed ammonium increased remarkably by increasing oxygen, $\mathrm{N}_{2}$ production increased slightly. This is because produced $\mathrm{NO}_{3}{ }^{-} \mathrm{N}$ by nitrifier was not completely conversed to $\mathrm{N}_{2}$ at high DO concentration. Fig. 4 shows that accumulation of 
$\mathrm{NO}_{3}{ }^{-} \mathrm{N}$ increased at high levels of DO. This experiment demonstrated that operation under higher DO concentration had negative effect on the denitrifying process, and conversion of nitrate and nitrite to be $\mathrm{N}_{2}$ gas was decreased. However, inoculation under DO concentration of 0.05-0.30 $\mathrm{mg} / \mathrm{L}$ slightly affected denitrifying bacteria, as shown in Table V. Reference [22] explained that denitrifying bacteria are facultative organisms; they can use either dissolved oxygen or nitrate as an oxygen source for metabolism and oxidation of organic matter. If dissolved oxygen and nitrate are present, bacteria will use the dissolved oxygen first. That is, the bacteria will not lower the nitrate concentration.

\section{Effect of DO on Simultaneous Removal of Sulfur and Nitrogen Compounds}

This study indicated that increasing DO concentrations leads to a drop in $\mathrm{SO}_{4}{ }^{2-}-\mathrm{S}$ removal efficiency while removed $\mathrm{NH}_{4}{ }^{+} \mathrm{N}$ was increased as shown in Table VI. The optimal DO concentration for simultaneous sulfate and nitrogen compound removal was $0.10-0.15 \mathrm{mg} / \mathrm{L}$. This condition provided removal efficiencies of $\mathrm{SO}_{4}{ }^{2-}-\mathrm{S}$ and $\mathrm{NH}_{4}{ }^{+}-\mathrm{N}$ at $71.3 \%$ and $68.2 \%$, respectively. Furthermore, the main metabolic products were $\mathrm{S}^{0}$ and $\mathrm{N}_{2}$ gas, yield of $\mathrm{S}^{0}$ and $\mathrm{N}_{2}$ was $0.63 \mathrm{~g} \mathrm{~S}^{0} / \mathrm{g} \mathrm{SO}_{4}{ }^{2-}-\mathrm{S}_{\text {added }}$ and $0.57 \mathrm{~g} \mathrm{~N}_{2} / \mathrm{g} \mathrm{NH}_{4}{ }^{+}-\mathrm{N}_{\text {added }}$, respectively. Reference [10] showed that sulfide was toxic to nitrifier in simultaneous sulfide and ammonium removal systems. However, produced sulfide by SRB in this experiment was oxidized by SOB under micro oxygen, which can mitigate the effect of sulfide on nitrifying bacteria. This work indicated that sulfate and nitrogen can be removed simultaneously under micro oxygen conditions. Table VI also showed that increasing DO concentration provided decreasing of produced $\mathrm{S}^{0}$. However, production of $\mathrm{N}_{2}$ gas was increased. The highest $\mathrm{S}^{0}$ yield of $0.69 \mathrm{~g}-\mathrm{S}^{0} / \mathrm{g}$ $\mathrm{SO}_{4}{ }^{2-}-\mathrm{S}_{\text {added }}$ was found at DO $0.05-0.10 \mathrm{mg} / \mathrm{L}$ and it was slightly decreased to $0.63 \mathrm{~g}-\mathrm{S}^{0} / \mathrm{g}_{-} \mathrm{SO}_{4}{ }^{2-}-\mathrm{S}_{\text {added }}$ at DO $0.10-0.15$ $\mathrm{mg} / \mathrm{L}$, which was not significantly different. In addition, $\mathrm{S}^{0}$ yield was decreased significantly at DO $0.15-0.30 \mathrm{mg} / \mathrm{L}$. In contrast, the lowest $\mathrm{N}_{2}$ yield was $0.43 \mathrm{~g}-\mathrm{N}_{2} / \mathrm{g}-\mathrm{NH}_{4}{ }^{+}-\mathrm{N}_{\text {added }}$ at DO $0.05-0.10 \mathrm{mg} / \mathrm{L}$, and it increased to 0.57 g- $\mathrm{N}_{2} / \mathrm{g}-\mathrm{NH}_{4}{ }^{+}-\mathrm{N}_{\text {added }}$ at DO $0.10-0.15 \mathrm{mg} / \mathrm{L}$. When DO concentration reached $0.15-0.20,0.20-0.25$ and $0.25-0.30$ $\mathrm{mg} / \mathrm{L}$, the yield of $\mathrm{N}_{2}$ was increased slightly. This work showed that the level of dissolved oxygen (DO) concentration may be an effective process parameter to regulate the specific microbial activities and their metabolic products.

TABLE VI: EFFECT OF DO ON SimultaNeOUS ReMOVAL OF SULFATE AND NITROGEN COMPOUNDS

\begin{tabular}{ccccc}
\hline \hline \multirow{2}{*}{$\begin{array}{c}\mathrm{DO} \\
\mathrm{mg} / \mathrm{L})\end{array}$} & \multicolumn{2}{c}{ Removal efficiency $(\%)$} & \multicolumn{2}{c}{ End product yield } \\
\cline { 2 - 5 } $\mathrm{SO}_{4}{ }^{2-}-\mathrm{S}$ & $\mathrm{NH}_{4}{ }^{+}-\mathrm{N}$ & $\mathrm{S}^{0 *}$ & $\mathrm{~N}_{2}{ }^{* *}$ \\
\hline $0.05-0.10$ & $78.0 \pm 3.8$ & $48.5 \pm 3.4$ & $0.69 \pm 0.05$ & $0.43 \pm 0.04$ \\
$0.10-0.15$ & $71.3 \pm 3.2$ & $62.8 \pm 2.8$ & $0.63 \pm 0.04$ & $0.57 \pm 0.03$ \\
$0.15-0.20$ & $48.4 \pm 3.6$ & $69.1 \pm 2.5$ & $0.44 \pm 0.03$ & $0.61 \pm 0.04$ \\
$0.20-0.25$ & $25.5 \pm 4.0$ & $72.9 \pm 3.2$ & $0.24 \pm 0.04$ & $0.64 \pm 0.03$ \\
$0.25-0.30$ & $5.6 \pm 2.4$ & $76.4 \pm 3.0$ & $0.05 \pm 0.05$ & $0.65 \pm 0.03$ \\
\hline \hline
\end{tabular}

* $\mathrm{S}^{0}$ yield $=\mathrm{g}$ of $\mathrm{S}^{0}$ produced $/ \mathrm{g}$ of $\mathrm{SO}_{4}{ }^{2-}-\mathrm{S}$ added

$* \mathrm{~N}_{2}{ }^{0}$ yield $=\mathrm{g}$ of $\mathrm{N}_{2}$ produced/g of $\mathrm{NH}_{4}{ }^{+}-\mathrm{N}$ added

\section{CONCLUSION}

This study showed that sulfate and nitrogen compounds can be removed simultaneously in a single reactor. The level of dissolved oxygen (DO) concentration was an effective process parameter to regulate the specific microbial activities and their metabolic products. The optimal DO concentration for simultaneous removal of sulfur and nitrogen compounds was $0.10-0.15 \mathrm{mg} / \mathrm{L} . \mathrm{S}^{0}$ and $\mathrm{N}_{2}$ gas were the main metabolic products of this process. Increasing DO concentration only $0.10 \mathrm{mg} / \mathrm{L}$ significantly inhibited SRB, leading to a decrease of sulfate removal efficiency and $\mathrm{S}^{0}$ production. In addition, when decreasing DO to $0.05-0.10 \mathrm{mg} / \mathrm{L}$, nitrifier was inhibited significantly and $\mathrm{N}_{2}$ production was decreased.

\section{ACKNOWLEDGMENT}

We gratefully acknowledge the support by the Joint Graduated School of Energy and Environment, and Excellent Center of Waste Utilization and Management, King Mongkut's University of Technology Thonburi, by Office of the Higher Education Commission (OHEC), by Agricultural research Development Agency (ARDA) and by Thaksin University, Thailand.

\section{REFERENCES}

[1] Y. Sun and M. Nemati, "Evaluation of sulfur-based autotrophic denitrification and denitritation for biological removal of nitrate and nitrite from contaminated waters," Bioresource Technology, vol. 114, pp. 207-216, 2012.

[2] A. Sarti, A. J. Silva, M. Zaiat, and E. Foresti, "The treatment of sulfate-rich wastewater using an anaerobic sequencing batch biofilm pilot-scale reactor," Desalination, vol. 249, pp. 241-246, 2009.

[3] X. Xu, C. Chen, A. Wang, W. Guo, X. Zhou, D. J. Leea, N. Ren, and J. S. Chang, "Simultaneous removal of sulfide, nitrate and acetate under denitrifying sulfide removal condition: Modeling and experimental validation," Journal of Hazardous Materials, vol. 264, 2014, pp. $16-24$.

[4] V. Midha, M. K. Jha, and A. Dey, "Sulfide oxidation in fluidized bed bioreactor using nylon support material," Journal of Environmental Sciences, vol. 24, no. 3, pp. 512-519, 2012

[5] J.-L. Wang, Y.-Z. Peng, S.-Y. Wang, and Y.-Q. Gao, "Nitrogen removal by simultaneous nitrification and denitrification via nitrite in a sequence hybrid biological reactor," Chinese Journal of Chemical Engineering, vol. 16, no. 5, pp. 778-784, 2008.

[6] X. J. Xu, C. Chen, A. J. Wang, N. Fang, Y. Yuan, N. Ren, and D. J. Lee, "Enhanced elementary sulfur recovery in integrated sulfate-reducing, sulfur-producing rector under micro-aerobic condition," Bioresource Technology, vol. 116, pp. 517-521, 2012.

[7] J. Reyes-Avila, E. Razo-Floresa, and J. Gomez, "Simultaneous biological removal of nitrogen, carbon and sulfur by denitrification," Water Research, vol. 38, pp. 3313-3321, 2004.

[8] C. Chen, N. Ren, A. Wang, L. Liu, and D. J. Lee, "Enhanced performance of denitrifying sulfide removal process under micro-aerobic condition," Journal of Hazardous Materials, vol. 179, 2010, pp. 1147-1151.

[9] C. Su, L. Zhu, C. Zhang, X. Qi, Y. Guo, and R. Gao, "Microbial community of aerobic granules for ammonium and sulphide removal in a sequencing batch reactor," Biotechnol. Lett., vol. 34, pp. 883-888, 2012.

[10] R. Beristain-Cardoso, D. N. Perez-Gonzalez, G. Gonzalez-Blanco, and J. Gomez, "Simultaneous oxidation of ammonium, p-cresol and sulfide using a nitrifying sludge in a multipurpose bioreactor: A novel alternative," Bioresource Technology, vol. 102, pp. 3623-3625, 2011.

[11] APHA, AWWA, WPCF, Standard Methods for Water and Wastewater Examination, $21^{\text {st }}$ ed. Washington, DC, USA, 2005.

[12] P. N. Lens, M.-P. de Poorter, C. C. Cronenberg, and W. H. Verstraete, "Sulfate reducing and methane producing bacteria in aerobic wastewater treatment systems," Wat. Res., vol. 29, no. 3, pp. 871-880, 1995.

[13] C. Rattanapan, D. Kantachote, R. Yan, and P. Boonsawang, "Hydrogen sulfide removal using granular activated carbon biofiltration inoculated 
with Alcaligenes faecalis T307 isolated from concentrated latex wastewater," International Biodeterioration and Biodegradation, vol. 64, pp. 383-387, 2010.

[14] A. J. H. Janssen, S. C. Ma, P. Lens, and G. Lettinga, "Performance of a sulfide-oxidizing expanded-bed reactor supplied with dissolved oxygen," Biotechnol. Bioeng., vol. 53, pp. 32-40, 1997.

[15] L. K. Baumgartner, R. P. Reid, C. Dupraz, A. W. Decho, D. H. Buckley, J. R. Spear, K. M. Przekop, and P. T. Visscher, "Sulfate reducing bacteria in microbial mats: changing paradigms, new discoveries," Sedimentary Geology, vol. 185, pp. 131-145, 2006.

[16] A. Dolla, M. Fournier, and Z. Dermoun, "Oxygen defense in sulfate-reducing bacteria," Journal of Biotechnology, vol. 126, pp. 87-100, 2006.

[17] C. A. Natália, S. A. C. Catarina, M. R. Suzana, A. D. R. José, Z. Marcelo, and F. Eugenio, "Effect of feeding strategy and COD/sulfate ratio on the removal of sulfate in an AnSBBR with recirculation of the liquid phase," Journal of Environmental Management, vol. 91, pp. $1756-1765,2010$

[18] P. N. L. Lens, A. Visser, A. J. H. Janssen, L. W. HulshoffPol, and G. Lettinga, "Biotechnological treatment of sulfate-rich wastewaters," Critical Reviews in Environmental Science and Technology, vol. 28, pp. 41-88, 1998.

[19] A. H. Nielsen, T. Hvitved-Jacobsen, and J. Vollertsen, "Kinetics and stoichiometry of sulfide oxidation by sewer biofilms," Water Res. vol.39, pp. 4119-4125, 2005.

[20] C. Chen, C. Zhou, A. J. Wang, D. H. Wu, L. H. Liu, N. Q. Ren, and D. J. Lee, "Elementary sulfur in effluent from denitrifying sulfide removal process as adsorbent for Zinc(II)," Bioresour. Technol., vol. 121, pp. 441-444, 2012

[21] L. B. Celis-Garcia, G. Gonzalez-Blanco, and M. Meraz, "Removal of sulfur inorganic compounds by a biofilm of sulfate reducing and sulfide oxidizing bacteria in a down-flow fluidized bed reactor," $J$. Chem. Technol. Biotechnol., vol. 83, pp. 260-268, 2008.

[22] W. Jianlong, P. Yongzhen, W. Shuying, and G. Yongqing, "Nitrogen Removal by Simultaneous Nitrification and Denitrification via Nitrite in a Sequence Hybrid Biological Reactor," Chinese Journal of Chemical Engineering, vol. 16, no. 5, pp. 778-784, 2008.

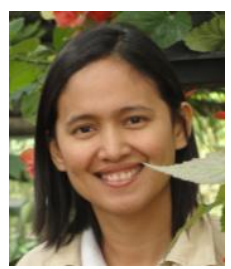

W. Thongnueakhaeng was born in Thailand on October 18, 1979. She got the bachelor's degree of environmental engineering from Prince of Songkla University, Songkhla, Thailand, 90110. She got the master degree of environmental science from The Joint Graduate School of Energy and Environment, King Mongkut's University of Technology Thonburi, Thailand, 10140.

She is a teacher at Thaksin University, Thailand, 93110 and she is now undertaking the Ph.D. at the Joint Graduate School of Energy and Environment, King Mongkut's University of Technology Thonburi, Thailand, 10140.

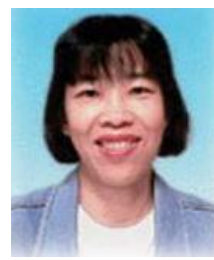

P. Chaiprasert was born in Thailand on February 18 1963. She got the B.Sc. degree in food science and technology from Chiang Mai University, Thailand; M.Sc. degree in biotechnology, King Mongkut's University of Technology Thonburi, Thailand and Ph.D. degree in environmental science from Florida Institute of Technology.

Now, she is an associate professor at King Mongkut's University of Technology Thonburi, Thailand and also the associate dean for Research, School of Bioresources and Technology.

Dr. Chaiprasert's research areas are in biological wastewater treatment, anaerobic wastewater treatment (biogas technology), solid waste treatment and utilization, composting of biological wastes, waste minimization and cleaner production. 